Research article

\title{
Macrophyte - environment relationships during a monospecific and a multispecific massive invasion in a fishpond
}

\author{
Lúcia H. Sipaúba-Tavares ${ }^{1}$, Cecilia B. Anatriello ${ }^{1}$, Ana Milstein ${ }^{2}$, \\ Rodrigo N. Millan ${ }^{3} \&$ Bruno Scardoeli-Truzzi ${ }^{1}$ \\ ${ }^{1}$ Aquaculture Center, Univ. Estadual Paulista - UNESP, Jaboticabal, São Paulo, Brazil \\ ${ }^{2}$ Agricultural Research Organization, Fish and Aquaculture Research Station Dor, \\ M.P. Hof HaCarmel, 30820 Israel \\ ${ }^{3}$ Universidade do Estado de Minas Gerais - UEMG, Department of Science, \\ Frutal, Minas Gerais, 38200-000 Brazil
}

*Corresponding Author: sipauba@ caunesp.unesp.br

[Accepted: 18 December 2017]

\begin{abstract}
The current study evaluated the water quality and zooplankton community in a shallow fish pond during two different macrophyte invasions, one of Salvinia auriculata only and the other of several aquatic plants. The results showed that the macrophyte covering of the pond surface led to anoxic conditions, not desirable in fish culture ponds. This negative effect occurred in winter and in summer, and under monospecific and multispecific macrophyte mass developments. The multispecific macrophyte invasion provided a more complex habitat structure that allowed higher zooplankton diversity and species richness but lower zooplankton density than the monospecific invasion. High organic loading may influence the mass development of floating macrophytes in one pond or another. To prevent macrophyte invasions it would be advisable to reduce organic loading in the pond system, which is a fish farm is rather difficult. But if a macrophyte invasion event occurs, proper management practices of plant removal can be applied to solve the immediate problem and to avoid sporocarps dissemination that could launch future such events. The management practices in the fish farm must be adequate to keep good water quality for the production of good market products.
\end{abstract}

Keywords: Salvinia auriculata - Sediment - Zooplankton community - Water quality.

[Cite as: Sipaúba-Tavares LH, Anatriello CB, Milstein A, Millan RN \& Scardoeli-Truzzi B (2017) Macrophyte - environment relationships during a monospecific and a multispecific massive invasion in a fishpond. Tropical Plant Research 4(3): 471-479]

\section{INTRODUCTION}

Macrophytes have a crucial role in the metabolism of shallow aquatic ecosystems. They exert considerable influence on the nutrient dynamics of water and sediment due to water shadowing and induction of particle sedimentation. They affect the habitat of the plankton community, particularly as a food source directly or indirectly through the periphyton growing on the macrophytes. Macrophyte species have specific and divergent traits that result from details in plant architecture, allelopathic activity, palatability for herbivores and association with certain organisms that may attract or repel zooplankton species (Van Onsem et al. 2010). The micro-invertebrate community associated to macrophytes consists of planktonic, phytophylus and micro-faunal species (Zrum \& Hann 1997). Dense beds of macrophytes are favorable to zooplankton development owing to the protection that plants provide against fish predation (Raut \& Pejaver 2013), and to increased water residence time that allows more time for the development of the zooplankton community (Basu et al. 2000).

Macrophyte presence in fish ponds remove nutrients and provide a large number of habitats for microinvertebrate species. However, if managed inadequately, invasive macrophytes may inflict harmful ecological and economic impacts on these systems (Chatterjee \& Dewanji 2014). Invasive macrophytes in fish ponds are 
not common, but when they massively occur they cause changes in biotic and abiotic water conditions that affect the whole ecosystem, causing serious problems in the use of ponds.

In southeastern Brazil, continuous water flow fish culture systems are used, where the water from one fishpond enters directly into the next one without previous treatment. Eventually, the water characteristics of the first fishpond may affect the following ones, increasing nutrients load. In this kind of system, the aquatic plants tend to propagate quickly and to cover the entire surface of the pond, mainly due to lack of adequate management (Sipaúba-Tavares et al. 2003).

Despite the widespread occurrence of macrophytes in shallow ecosystems in neotropical regions and their potentially harmful impacts on the environment, state-of-the-art information on invasive macrophyte effects with regard to water conditions and zooplankton community in fish ponds is still rare. The current study evaluated two different massive macrophyte invasions, one only with Salvinia auriculata Aublet (monospecific) and other with several aquatic plants (multispecific) that developed in the same fish pond, and their influence on the zooplankton community and water column.

\section{MATERIAL AND METHODS}

Study Area

The current study was performed in a fish pond of the aquaculture farm of the University of São Paulo State

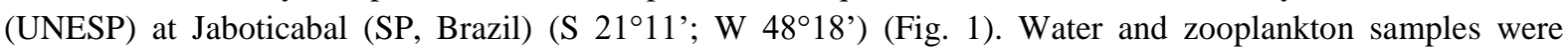
collected during two macrophyte invasion periods: one in summer 2009 when a monospecific invasion of Salvinia auriculata (SA) developed, and the other in autumn/winter 2010 when an invasion of multiple macrophytes species (MS) occurred. The fish pond under analysis has a surface area of 4,268 $\mathrm{m}^{2}$, a maximum depth of $1.3 \mathrm{~m}$, with continuous water flow and water renewal equivalent to $5 \%$ of its total volume/day (calculated by discharge volume). It is the fourth in a sequential series of six similar size fish ponds (areas ranging between $2,036 \mathrm{~m}^{2}$ and $8,067 \mathrm{~m}^{2}$ ), each directly and/or indirectly receiving water from the previous one through an underground pipe grid (Fig. 1). This fish pond has two water inlets at its northern end, receiving water from the previous fish ponds in the line and from a total of forty-nine small fish ponds with areas between $45 \mathrm{~m}^{2}$ and $400 \mathrm{~m}^{2}$, as well as from a frog culture sector. The water outlet lies at the south end of the fish pond.

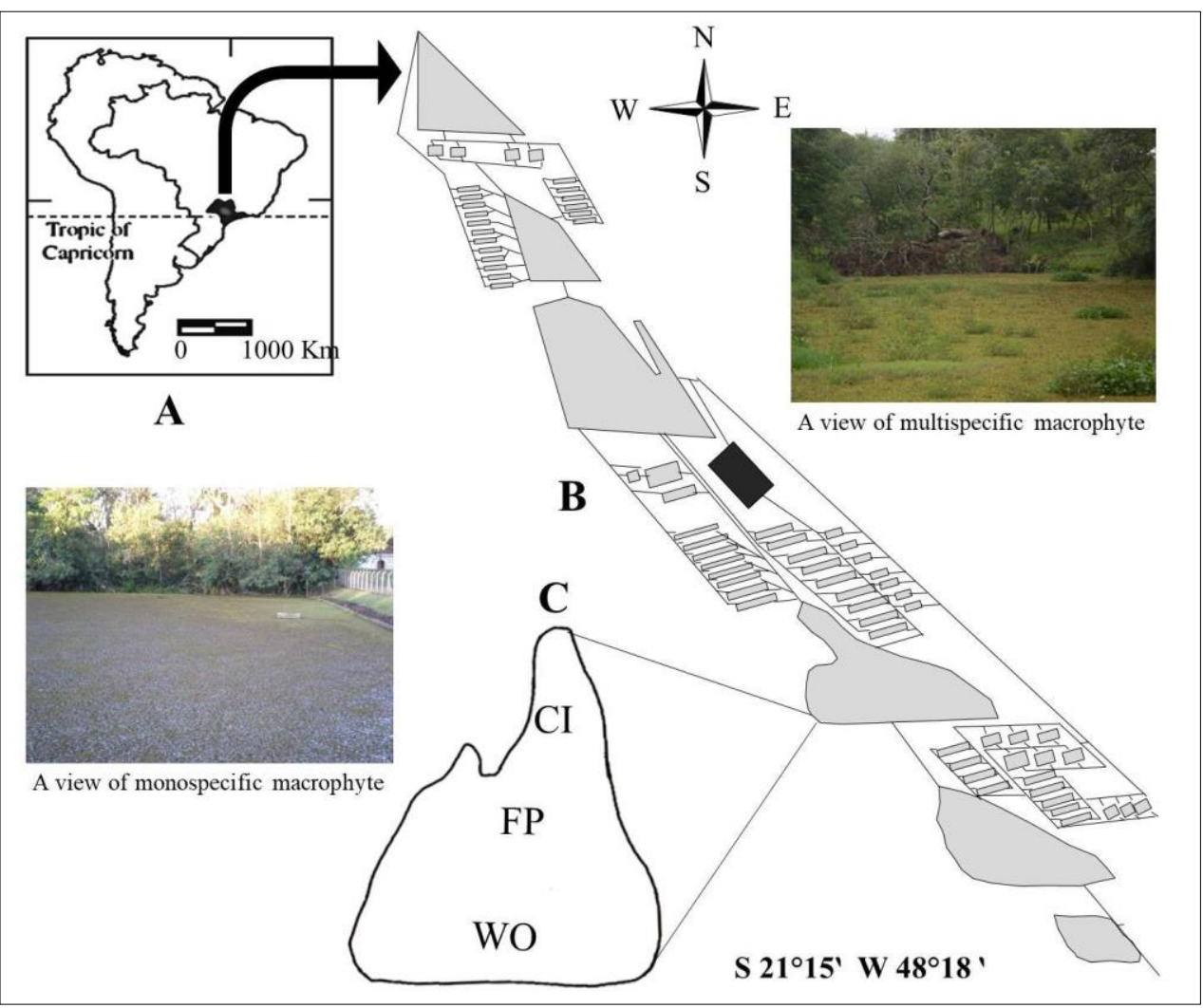

Figure 1. Diagram of the fish pond studied. Inset A: shaded area indicates southeastern Brazil (the state of São Paulo). Inset B: aquaculture farm of the Univ. Estadual Paulista. Inset C: fishpond studied with sampling sites (CI, FP, and WO) and $=$ frog culture sector. 
The fish species present in the pond during the Salvinia auriculata invasion were Oreochromis niloticus, Ctenopharyngodon idella, Colossoma macropomum and Piaractus mesopotamicus at a total density of approximately $0.5 \mathrm{~kg} \cdot \mathrm{m}^{-2}$. During the second invasion (multispecific) the fish pond had about 400 Ctenopharyngodon idella individuals. Fish were fed during both invasions with a supplementary diet at a rate of $3 \%$ of their weight per day.

\section{Macrophytes Handling and Sampling}

The initial monospecific Salvinia auriculata invasion in 2009 covered the total surface area of the fish pond. The species was harvested by several people that entered into the pond, removed the plants by hand and deposited them on the pond banks. After the physical removal of S. auriculata, the fish pond was drained, refilled and fish were stocked in the fish pond.

Macrophyte sampling at the end of the second invasion period was performed using a $1 \mathrm{~m}^{2}$ quadrat. All macrophyte materials collected in 6 quadrants taken throughout the pond were carefully identified and measured to determine the coverage (\%) of each species as indicated by Thomaz et al. (2004).

\section{Environmental Parameters Sampling}

Environmental parameters were determined always in the morning, at about 8:00. Surface water was weekly sampled with a 1L Van Dorn bottle at three sampling sites, CI = close to water inlets; FP = deep water site; WO = water outlet (Fig. 1). Sampling was performed from a boat taking care not to disturb sediments in the sampling point. Water temperature (Temp), dissolved oxygen (DO), conductivity (Cond) and $\mathrm{pH}$ were measured in situ with a Horiba U-10 multi-sensor. Total phosphorus (TP) and nitrogen compounds were quantified by spectrophotometer following Golterman et al. (1978) and Koroleff (1976). Alkalinity (Alk) was determined as described by Mackereth et al. (1978) and chlorophyll-a (Chlor-a) was extracted with alcohol $90 \%$ and quantified at $663 \mathrm{~nm}$ and $750 \mathrm{~nm}$ (Nusch 1980). Total suspended solids (TSS), total dissolved solids (TDS) and 5-day biochemical oxygen demand $\left(\mathrm{BOD}_{5}\right)$ were determined according to Boyd \& Tucker (1992). Water samples for microbiological analysis using the multiple-tube methods were collected in $500 \mathrm{~mL}$ flasks and taken to the laboratory in an isothermal container. The material for microbiological analysis and thermotolerant coliforms (TC) was sterilized prior to use (APHA 1995).

Zooplankton sampling was weekly performed filtering $10 \mathrm{~L}$ of water through a $58 \mu \mathrm{m}$ pore net. The collected material was concentrated to $50 \mathrm{ml}$ and formaldehyde was added to reach $4 \%$ of final concentration. Net samples were observed under optical microscope for preliminary taxonomical identification. Copepoda and Cladocera species were counted in a reticulated acrylic chamber under a stereoscopic microscope $(40 \mathrm{X})$ and Rotifera were analyzed by counting organisms with a Sedgewick-Rafter chamber under a Leitz microscope (100 X). Taxonomic identification followed specialized literature (Koste 1978, Reid 1985, Elmoor-Loureiro 1997).

\section{Data Analysis}

All water parameters underwent one-way analysis of variance (ANOVA) and post-hoc Tukey's HSD multiple comparison test with Statistica 8.0 to compare sites (CI, FP and WO) and macrophyte invasion periods at a $P<0.05$ significance level. In all cases, ANOVA was preceded by a test of variance homogeneity (Levene's test). All results were expressed as Means \pm Standard Deviation (SD). Analyses of zooplankton species dominance (d) and abundance (a) were also conducted. Species were considered dominant when their density was higher than $50 \%$ of the total number of specimens present in each sampling site and invasion period; they were abundant when the number of specimens was higher than the mean density of all occurring species (Lobo \& Leighton 1986). The Shannon-Wiener (H') and richness (total number of species) indexes were calculated from the total number of zooplankters present in each sampling site and invasion period. Sites were grouped by cluster analysis (unweighted pair group average linkage, UPGMA) based on Bray Curts Index, using abundance $\log _{10}(x+1)$ transformed data of all zooplankton (Valentin 2000).

\section{RESULTS}

The initial monospecific macrophyte invasion in summer 2009 by the free-floating fern Salvinia auriculata covered in two months the total surface area of the fish pond. During the second invasion period in autumnwinter 2010, multiple macrophytes species occurred: the small free-floating plants S. auriculata and Lemna minor L. covered $49 \%$ of the occupied pond area, the bigger free-floating plant Eichhornia crassipes (Mart.) a further 33\%, the ground and floating grass Panicum repens L. and the prostrate herb Polygonum capitatum another 10\%, and the rooted species Typha domingensis Pers. and Cyperus rotundus L. an additional $8 \%$. www.tropicalplantresearch.com 
Starting with $S$. auriculata development, the multispecies invasion covered in two months the total surface of the fish pond.

Table 1. Water variables and thermotolerant coliforms (Mean \pm Standard deviation during the sampling period) in the fish pond under the invasions of Salvinia auriculata (SA) and multiple macrophytes species (MS) in three sampling sites: $\mathrm{CI}=$ Close to water inlets; $\mathrm{FP}=$ Deep-water; $\mathrm{WO}=$ Water outlet.

\begin{tabular}{|c|c|c|c|c|c|c|}
\hline \multirow{2}{*}{ Variables } & \multicolumn{3}{|c|}{ SA (summer) } & \multicolumn{3}{|c|}{ MS (autumn-winter) } \\
\hline & CI & FP & WO & CI & FP & WO \\
\hline Temp $\left({ }^{\circ} \mathrm{C}\right)$ & $27 \pm 1^{\mathrm{a}}$ & $26 \pm 0.4^{\mathrm{ab}}$ & $26 \pm 0.5^{b}$ & $20 \pm 1^{\mathrm{c}}$ & $20 \pm 1^{\mathrm{c}}$ & $19 \pm 1^{\mathrm{c}}$ \\
\hline $\mathrm{pH}$ & $9 \pm 0.2^{\mathrm{a}}$ & $9 \pm 0.2^{\mathrm{a}}$ & $9 \pm 0.1^{\mathrm{a}}$ & $6 \pm 0.4^{\mathrm{b}}$ & $6 \pm 1^{\mathrm{b}}$ & $6 \pm 1^{\mathrm{b}}$ \\
\hline Cond $\left(\mu\right.$ S.cm $\left.{ }^{-1}\right)$ & $116 \pm 5^{\mathrm{a}}$ & $121 \pm 9^{\mathrm{a}}$ & $120 \pm 5^{\mathrm{a}}$ & $87 \pm 16^{\mathrm{b}}$ & $95 \pm 6^{\mathrm{b}}$ & $90 \pm 7^{\mathrm{b}}$ \\
\hline $\operatorname{Alk}\left(\mathrm{mg} \cdot \mathrm{L}^{-1}\right)$ & $115 \pm 21^{\mathrm{a}}$ & $119 \pm 30^{\mathrm{a}}$ & $116 \pm 30^{\mathrm{a}}$ & $105 \pm 6^{\mathrm{a}}$ & $107 \pm 16^{\mathrm{a}}$ & $105 \pm 11^{\mathrm{a}}$ \\
\hline $\mathrm{DO}\left(\mathrm{mg} \cdot \mathrm{L}^{-1}\right)$ & $5 \pm 0.2^{\mathrm{a}}$ & $1 \pm 0.1^{\mathrm{bc}}$ & $1 \pm 0.2^{\mathrm{c}}$ & $4 \pm 1^{\mathrm{a}}$ & $2 \pm 1^{\mathrm{b}}$ & $1.4 \pm 1^{\mathrm{bc}}$ \\
\hline $\mathrm{TP}\left(\mu \mathrm{g} . \mathrm{L}^{-1}\right)$ & $207 \pm 46^{\mathrm{a}}$ & $203 \pm 69^{a b}$ & $189 \pm 56^{\mathrm{ab}}$ & $82 \pm 47^{\mathrm{b}}$ & $85 \pm 42^{\mathrm{b}}$ & $210 \pm 145^{\mathrm{a}}$ \\
\hline TAN $\left(\mu \mathrm{g} . \mathrm{L}^{-1}\right)$ & $526 \pm 38^{\mathrm{b}}$ & $440 \pm 51^{\mathrm{bc}}$ & $262 \pm 50^{c}$ & $1,089 \pm 243^{\mathrm{a}}$ & $955 \pm 221^{\mathrm{a}}$ & $1,034 \pm 146^{\mathrm{a}}$ \\
\hline Nitrite $\left(\mu \mathrm{g} . \mathrm{L}^{-1}\right)$ & $22 \pm 5^{\mathrm{a}}$ & $21 \pm 3^{\mathrm{a}}$ & $13 \pm 2^{\mathrm{b}}$ & $20 \pm 5^{\mathrm{a}}$ & $22 \pm 10^{\mathrm{a}}$ & $15 \pm 8^{\mathrm{b}}$ \\
\hline Nitrate $\left(\mu \mathrm{g} \cdot \mathrm{L}^{-1}\right)$ & $224 \pm 63^{c}$ & $467 \pm 150^{b}$ & $327 \pm 85^{\mathrm{bc}}$ & $374 \pm 55^{\mathrm{bc}}$ & $720 \pm 51^{\mathrm{a}}$ & $392 \pm 242^{\mathrm{bc}}$ \\
\hline $\mathrm{BOD}_{5}\left(\mathrm{mg} \cdot \mathrm{L}^{-1}\right)$ & $7 \pm 0.6^{a}$ & $4.5 \pm 1.5^{\mathrm{b}}$ & $4.8 \pm 1.5^{\mathrm{b}}$ & $7 \pm 1^{\mathrm{a}}$ & $5 \pm 1^{\mathrm{b}}$ & $5 \pm 1^{\mathrm{b}}$ \\
\hline TSS $\left(m g . L^{-1}\right)$ & $11 \pm 3^{\mathrm{a}}$ & $12 \pm 7^{\mathrm{a}}$ & $10 \pm 9^{\mathrm{a}}$ & $9 \pm 1^{\mathrm{a}}$ & $13 \pm 1^{\mathrm{a}}$ & $16 \pm 3^{\mathrm{a}}$ \\
\hline TDS (mg. $\left.\mathrm{L}^{-1}\right)$ & $100 \pm 21^{\mathrm{a}}$ & $83 \pm 21^{\mathrm{a}}$ & $88 \pm 17^{\mathrm{a}}$ & $98 \pm 15^{\mathrm{a}}$ & $82 \pm 29^{a}$ & $106 \pm 27^{\mathrm{a}}$ \\
\hline Chlor-a $\left(\mu \mathrm{g} . \mathrm{L}^{-1}\right)$ & $43 \pm 10^{\mathrm{b}}$ & $45 \pm 15^{\mathrm{b}}$ & $37 \pm 8^{\mathrm{b}}$ & $96 \pm 23^{a}$ & $67 \pm 45^{\mathrm{ab}}$ & $55 \pm 14^{\mathrm{b}}$ \\
\hline TC (MPN.100mL $\mathrm{mL}^{-1}$ ) & $1,259 \pm 173^{\mathrm{a}}$ & $1,009 \pm 394^{\mathrm{a}}$ & $967 \pm 352^{\mathrm{a}}$ & $33 \pm 21^{\mathrm{b}}$ & $22 \pm 18^{\mathrm{b}}$ & $14 \pm 8^{\mathrm{b}}$ \\
\hline
\end{tabular}

Note: Values in the same row with different superscripts are significantly different ( $<<0.05)$; TAN = total ammonia nitrogen.

The ANOVA results of the water variables measured in each macrophyte invasion period and sampled site are presented in table 1. As expected, temperature was significantly higher during the summer than during the winter. During the summer $S$. auriculata invasion period were recorded significantly lower TAN and significantly higher $\mathrm{pH}$, conductivity and thermotolerant coliforms than in the multispecific winter invasion period. Thermotolerant coliforms were 2 orders of magnitude lower during the multiple species invasion period. Some variables presented differences among sampling sites in one or both invasion periods. In both periods dissolved oxygen and $\mathrm{BOD}_{5}$ were significantly higher close to the water inlets nitrate was significantly higher in the center of the pond, while nitrite was significantly higher in the output area. During the summer period there were decreasing temperature and TAN gradients from the water input to the water output, while during the winter period both parameters were homogeneous in the whole pond. Total phosphorus was homogeneously high in the whole pond during the SA invasion, while during the MS invasion it was significantly lower in the inlet and central areas. No differences among sites and periods were recorded in alkalinity, TSS and TDS.
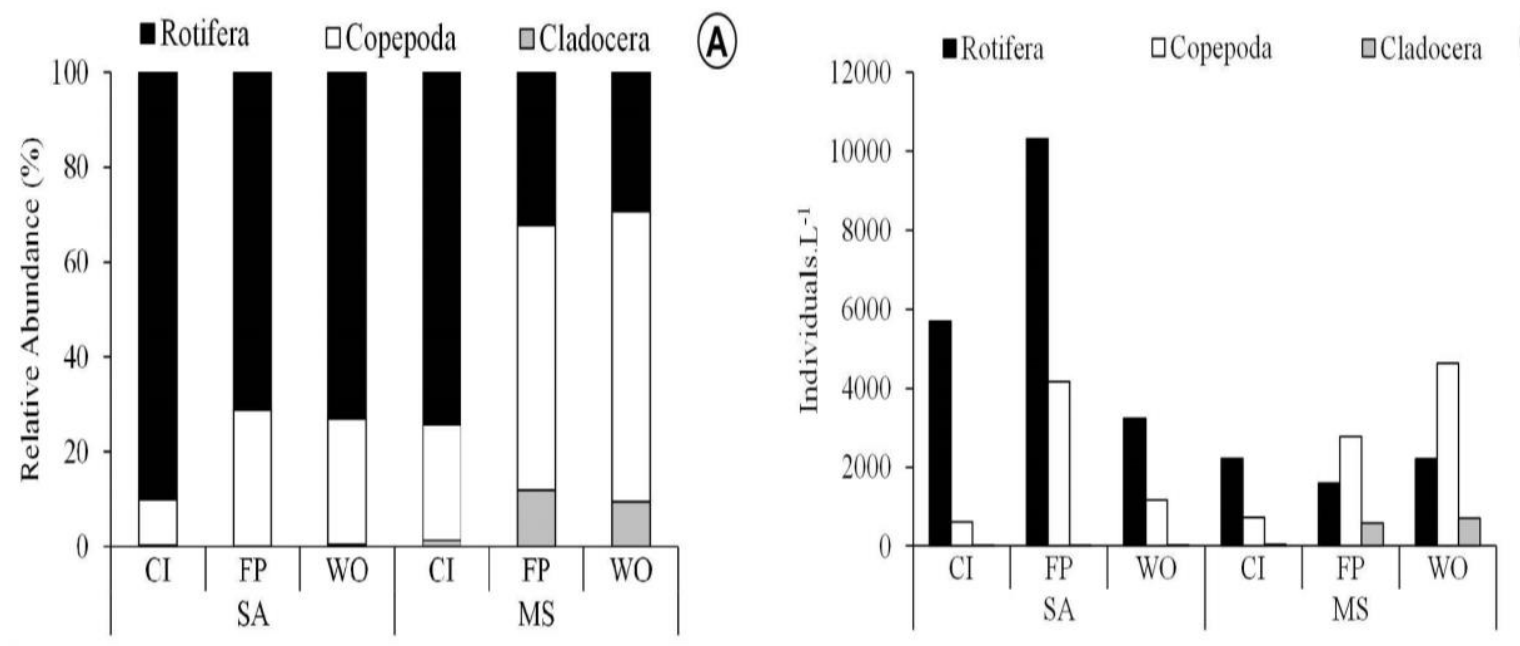

(B)

Figure 2. Zooplankton during the sampling period, under the invasions with Salvinia auriculata (SA) and multiple macrophyte species (MS) in different sampling site $(\mathrm{CI}=$ close to water inlets; $\mathrm{FP}=$ deep-water sites; $\mathrm{WO}=$ water outlet): $\mathbf{A}$, Mean relative abundance (\%); B, Density (individuals. $\mathrm{L}^{-1}$ ). 
Zooplankton was composed by Rotifera, Cladocera and Copepoda. Rotifera constituted most of the zooplankton (70-90\%) and had higher density $\left(3,200-10,300\right.$ ind. $\left.\mathrm{L}^{-1}\right)$ during the SA invasion, while during the MS invasion their density was lower (1,600-2,200 ind. $\left.\mathrm{L}^{-1}\right)$ and they were the most abundant group only near the inlets (74\% in CI vs. 30\% in FP and WO) (Fig. 2). Copepoda was the second most abundant group, representing 55-60\% of total zooplankton only during the MS invasion in the FP and WO sites, with similar densities but different spatial distributions within the pond in both invasion periods (Fig. 2). Cladocera was the least abundant group, with just a few organisms during the SA invasion and up to 700 ind. $\mathrm{L}^{-1}$ (10\% of zooplankton), during the MS invasion (Fig. 2).

Table 2. Specific composition, abundance and ecological indexes (diversity and species richness) of zooplankton in the fish pond under the invasions of Salvinia auriculata (SA) and of multiple macrophytes species (MS), in three sampling sites: $\mathrm{CI}=$ close to water inlets; FP = deep-water site; $\mathrm{WO}=$ water outlet.

\begin{tabular}{|c|c|c|c|c|c|c|c|}
\hline \multirow{2}{*}{\multicolumn{2}{|c|}{ Taxa }} & \multicolumn{3}{|c|}{$\mathbf{S A}$} & \multicolumn{3}{|c|}{ MS } \\
\hline & & CI & FP & WO & CI & FP & WO \\
\hline & Diversity (H') & 0.33 & 0.60 & 0.61 & 0.62 & 0.94 & 0.88 \\
\hline & Species richness & 27 & 20 & 20 & 32 & 23 & 22 \\
\hline
\end{tabular}

Alona monacantha (Sars, 1901)

Bosmina hagmanni (Stingelin, 1904)

Diaphanosoma birgei (Korineck, 1981

Copepoda

Argyrodiaptomus furcatus (Sars, 1901) Nauplii

Thermocyclops decipiens (Lowndes, 1934)

Nauplii

Harpacticoida Nauplii

\section{Rotifera}

Ascomorpha agilis (Zacharias, 1893)

Ascomorpha ecaudis (Perty, 1850)

Asplanchna sp. (Guerne, 1888)

Asplanchnopus sp. (Guerne, 1888)

Brachionus calyciflorus (Pallas, 1766)

Brachionus caudatus (Barrois \& Daday, 1894)

Brachionus falcatus (Zacharias, 1898)

Brachionus havanaensis (Rousselet, 1911)

Brachionus quadridentatus (Hermann, 1783)

Brachionus patulus (Muller, 1786)

Cephalodella remanei (Wiszniewski, 1934)

Colurella uncinata (Ehrenberg, 1832)

Euchlanis arenosa (Myers, 1936)

Filinia terminalis (Plate, 1886)

Keratella cochlearis (Gosse, 1851)

Keratella serrulata (Ehrenberg, 1838)

Keratella tropica (Apstein, 1907)

Lecane bula (Gosse, 1851)

Lecane elsa (Hauer, 1931)

Lecane proiecta (Hauer, 1956)

Lecane submagna (De Ridder, 1960)

Lepadella heterostyla (Murray, 1913)

Lepadella ovalis (Müller, 1786)

Platyias quadricornis (Ehrenberg, 1832)

Polyarthra dolichoptera (Idelson, 1925)

Proales doliaris (Rousselet, 1895)

Proales globulifera (Hauer, 1921)

Proales sordida (Gosse, 1886)

Proalinopsis caudatus (Collins, 1873)

Synchaeta stylata (Wierzejski, 1893)

Testudinella mucronata (Gosse, 1886)

Trichocerca longiseta (Schrank, 1802)

\begin{tabular}{llllll}
+ & + & + & + & $\mathrm{a}$ & $\mathrm{a}$ \\
+ & + & + & - & - & - \\
+ & + & + & + & + & + \\
\hline
\end{tabular}

Note: a, Abundance; +, Present; -, Absent.

www.tropicalplantresearch.com 
Zooplankton species diversity and richness were higher during the multispecies macrophyte invasion. Together with this, in both period diversity was lower and richness was higher near the inlets than in the center and outlet areas (Table 2). Cluster analysis based on zooplankton composition and densities showed that during the SA invasion the inlets and outlet areas were similar and different from the pond center, while during the MS invasion the inlets area was markedly different from the other sites (Fig. 3).
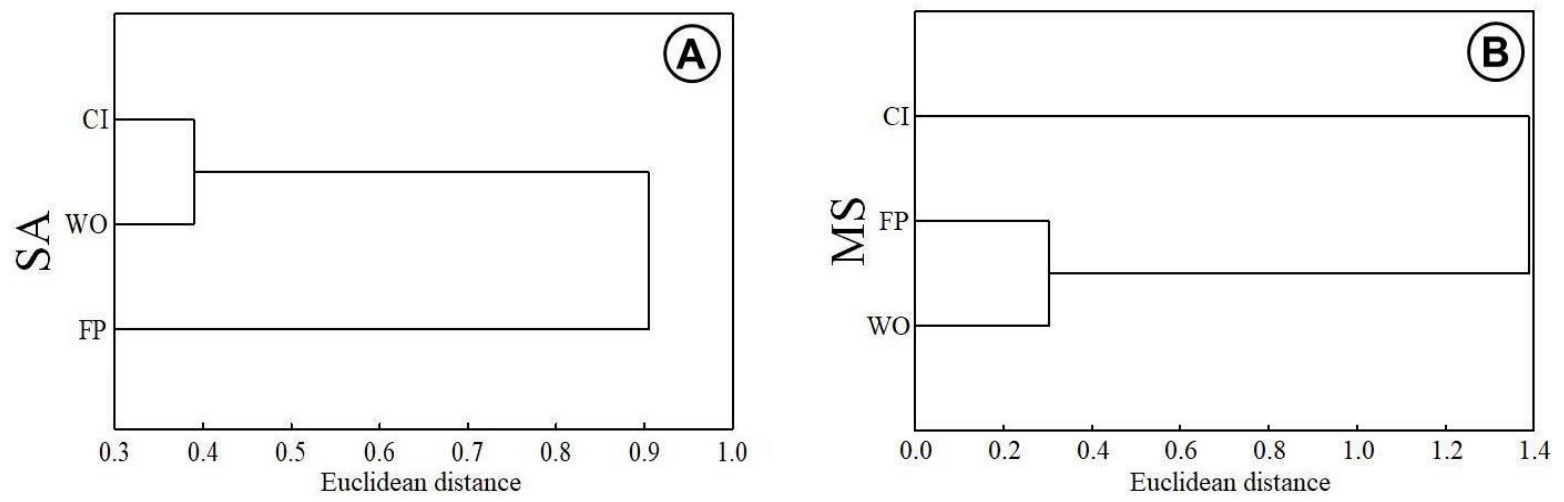

Figure 3. Cluster analysis of total average densities of zooplankton (individuals. $\mathrm{L}^{-1}$ ) in each sampling site under the invasions with macrophyte: A, Salvinia auriculata (SA); B, Multiple species (MS).

Overall, in the zooplankton occurred 32 species of Rotifera, 3 of Cladocera and 3 of Copepoda (Table 2). None of the recorded species was dominant in any site or invasion period. Two species of Copepoda, 2 of Cladocera, and 3 of Rotifera (Poliarthra dolichoptera, Proales doliaris, Trichocerca longiseta) occurred in all sampled sites in both invasion periods. The Cladocera Bosmina hagmanni and 6 Rotifera species (Asplanchna sp., Brachionus caudatus, B. havanaensis, B. quadridentatus, Lecane elsa, L. proiecta) were recorded only during the SA invasion period. No Crustacea and 6 Rotifera species (Lecane submagna, Lepadella heterostyla, L. ovalis, Platyias quadricornis, Proales sordida, Synchaeta stylata) were recorded only during the MS invasion period. Five Rotifera species (Ascomorpha ecaudis, Lecane elsa, L. proiecta, Proales sordida, Proalinopsis caudatus) only occurred in the water inlet area. During the SA invasion period the abundant taxa in the whole pond were nauplii of the Copepoda Thermocyclops decipiens and the Rotifera Polyarthra dolichoptera and Trichocerca longiseta. Abundant in the inlet and/or center areas were also Keratella serrulata and Proales doliaris, and in the outlet area Filinia terminalis. During the MS invasion period only nauplii of the Copepoda T. decipiens were abundant in the entire pond. In the inlet area were also abundant the Rotifera Brachionus calyciflorus, Keratella serrulata, K. tropica, Polyarthra dolichoptera, Trichocerca longiseta, and Proales doliaris that also was abundant in the center of the pond. In contrast, in the central and outlet areas the abundant taxa were crustaceans: the Cladocera Alona monacantha and all developmental forms of the Copepoda $T$. decipiens. Nauplii of the Copepoda Argyrodiaptomus furcatus were abundant only in the outlet area.

\section{DISCUSSION}

Macrophyte presence in this aquaculture farm is rather common, mainly in the six larger ponds. Although this presence generally does not compromise the well-functioning of the system, it represents a potential threat as a source for an aggressive macrophyte development. When a macrophyte invasion occurs it is important to study such events in order to acquire knowledge for the better management of the ecosystem. At the time of our studies the aggressive development occurred only in this pond, not in the previous or posterior ones, indicating that appropriate conditions for such developments were rather localized. The invasions occurred during different seasons, which introduce some degree of confounding between seasonal and macrophyte effects on the observed differences between both periods. This could not be avoided since the invasions naturally occurred (as opposed to experimentally induced) in such periods. We do not know which, were the conditions that led to the monospecific Salvinia auriculata invasion, but we have a hypothesis to explain the second multispecific invasion. The hypothesis is that there is a link between the incorrect plant removal in the summer 2009 and the multispecies invasion in the autumn-winter 2010. During that removal operation, the workers walking in the pond disrupted pond bottom, water column and S. auriculata integrity, so that sporocarps and broken parts of the plants should have remained in the pond. Sporocarps and plant material should have also entered the pond as rains washed the removed macrophyte biomass left on the pond banks. These sporocarps allowed the appearance of $S$. auriculata the next year, which became a substrate for the natural growth of other macrophytes www.tropicalplantresearch.com 
ending up in the multispecies invasion. The multispecies invasion was removed by a professional team that pushed nets from the banks without disturbing the pond bottom, and did not leave the removed material on the banks. No further macrophyte invasion was recorded the following years in this pond.

Both studied invasions were only or largely dominated by floating macrophyte species. In small water bodies, where water flow or winds cannot wipe them out, dense beds of free-floating plants are a symptom of high-nutrient loading. This is because, having no direct access to the sediment pool of nutrients, floating plants depend on high nutrient concentrations in the water for their growth (Scheffer et al. 2003). In our study, effluents of fish ponds and frog culture facilities are the main source of organic and inorganic matter entering the pond. Fish and frog culture activities are more intense during the summer (higher density, feeding rate, etc), hence the higher concentrations of salts (conductivity), total phosphorus and thermotolerant coliforms observed during this season. Summer is also the rainy season, clouds reducing light for phytoplankton photosynthesis in fish ponds without macrophyte cover, hence reducing the amount of planktonic chlorophyll entering our macrophyte covered pond. In contrast to those variables whose winter-summer differences were mostly related to the water quality entering the pond, TAN concentration is also strongly determined by processes such as decomposition, absorption and nitrification occurring within the pond, which led to lower TAN levels during the warm season. TAN release into the water column through organic matter decomposition seems to have been similar during both studied periods, as indicated by the similar $\mathrm{BOD}_{5}$, TSS and TDS levels measured in both periods. But TAN removal from the water column through absorption may account for its lower concentration in summer than in winter, since under higher temperature the increased metabolism of the large macrophyte biomass present in the pond should have absorbed/removed more of it. TAN removal from the water column through nitrification occurred in both periods, as indicated by the presence of nitrate together with the almost absence of nitrite; the higher TAN availability as substrate for nitrification in winter would explain the overall higher nitrate levels observed during that period.

Floating plants capacity to remove nutrients may be used to improve water quality. Specifically for Salvinia auriculata and Eichhornia crassipes, the main floating macrophytes in our study, in another pond of the same farm it was found that they efficiently reduced levels of nitrate, total phosphorus and orthophosphate (SipaúbaTavares et al. 2003). However, when free-floating plants form dense extensive mats, they have adverse effects on freshwater ecosystems because they create anoxic conditions, which strongly reduce animal biomass and diversity and hamper fish production (Scheffer et al. 2003, Chatterjee \& Dewanji 2014). This may have occurred in our study, since oxygen concentrations were under $1.5 \mathrm{mg} . \mathrm{L}^{-1}$ during all SA invasion and most of the time during the MS invasion. Only in the inlet area, where the entering water falls from a height of $1 \mathrm{~m}$ over the pond surface strongly mixing the water, oxygen was over $4 \mathrm{mg} \cdot \mathrm{L}^{-1}$ during both invasion periods.

In a flow-through system, macrophyte reduce water flow rate within the pond promoting particle sedimentation, as indicated by the low sub-surface amount of suspended particles (TSS) observed throughout the pond during both macrophyte covered periods.

The abundance of the mesotrophic-eutrophic environments copepod bio-indicator Thermocyclops decipiens (Tibúrcio et al. 2015) and the large amounts of Rotifera observed in both studied periods respond to the high nutrient and organic loadings always entering the pond. The differences in zooplankton species composition observed in both invasion periods seem not to be largely related to season, since 38 out of the 40 taxa in table 2 have been recorded during the rainy summer and during the dry winter either in this or in previous macrophyte studies conducted in this farm (Travaini-Lima et al. 2016, Sipaúba-Tavares et al. 2017). The exceptions are the Rotifera Brachionus havanaensis and B. quadridentatus that here and in the work of Travaini-Lima et al. (2016) where observed only during the rainy summer. Thus, the higher zooplankton diversity and species richness during the multispecies invasion may be considered an indication of the more complex habitat structure provided by several floating and rooted macrophytes as compared to the simpler habitat structure provided only by one macrophyte free-floating species.

Summing up, macrophyte covering of the pond surface led to anoxic conditions, not desirable in fish culture ponds. This negative effect occurred in winter and in summer, and under monospecific and multispecific macrophyte mass developments. The multispecific macrophyte invasion provided a more complex habitat structure that allowed higher zooplankton diversity and species richness but lower zooplankton density than the monospecific invasion. High organic loading may influence the mass development of floating macrophytes in one pond or another. To prevent macrophyte invasions it would be advisable to reduce organic loading in the pond system, which in a fish farm is rather difficult. But if a macrophyte invasion event occurs, proper www.tropicalplantresearch.com 
management practices of plant removal can be applied to solve the immediate problem and to avoid sporocarps dissemination that could launch future such events. The management practices in the fish farm must be adequate to keep good water quality for the production of good market products.

\section{ACKNOWLEDGEMENTS}

The authors would like to thank the Brazilian Council for Scientific and Technological Development (CNPq - PQ II) and the Foundation for Research Support of the State of São Paulo (FAPESP) for the scholarship awarded to the second author (09/51852-1 and 12/06382-0) and for funding (12/09884-4).

\section{REFERENCES}

APHA (1995) Standard methods for the examination of water and wastewater, 19 ed. APHA, Washington, 1100 p.

Basu BK, Kalff J \& Pinel-Alloul B (2000) The influence of macrophyte bed on plankton communities and their export from fluvial lakes in the St Lawrence river. Freshwater Biology 45(4): 373-382.

Boyd CE \& Tucker CS (1992) Water quality and pond soil analyses for aquaculture. Agricultural Experiment Station, Alabama, 183 p.

Chatterjee A \& Dewanji A (2014) Effect of varying Althernanthera philoxeroides (alligator weed) cover on the macrophyte species on diversity of pond ecosystems: a quadrat-based study. Aquatic Invasions 9(3): 343355.

Elmoor-Loureiro LMA (1997) Manual de identificação de cladóceros límnicos do Brasil. Editora UniversaUCB, Taguatinga, 156 p. (in Portuguese)

Golterman HL, Clymo RS \& Ohnstad MAM (1978) Methods for physical and chemical analysis of fresh water, 2 ed. Oxford: Blackwell Scientific Publication, 213 p.

Koroleff F (1976) Determination of Ammonia. In: Grashof K \& Kremlingorg E (eds) Methods of seawater analysis. Verlag Chemie Weinheim, Germany, pp. 126-133.

Koste W (1978) Rotatoria. Die RaÈdertiere Mitteleuropas, vol. 2. Borntraeger, Berlin, 673 p.

Lobo E \& Leighton G (1986) Estructuras comunitarias de las fitocenosis planctonicas de los sistemas de desembocaduras de ríos y esteros de la zona central de Chile. Revista de Biología Marina y Oceanografía 22(1): 1-29.

Mackereth FJ, Heron HJ \& Talling FJ (1978) Water analyses: some revised methods for limnologists. Freshwater Publication Association Scientific Publication 36: 22-117.

Nusch EA (1980) Comparison of different methods for chlorophyll and phaeopigment determination. Archiv für Hydrobiologie 14: 14-36.

Raut NS \& Pejaver MK (2013) Comparative study on variation of plankton of macrohyte infested and noninfested lakes from Thane city, Maharashra. In: National Conference on Biodiversity: Study and Challenges in Conservation - FAVEO, pp. 177-180.

Reid JW (1985) Calanoid copepods (Diaptomidae) from coastal lakes. State of Rio de Janeiro. Brazil. Proceedings of the Biological Society Washington 98(1): 574-590.

Scheffer M, Szabó S, Gragnani A, van Nes EH, Rinaldi S, Kautsky N, Norberg J, Roijackers RMM \& Franken RJM (2003) Floating plant dominance as a stable state. Proceedings of the National Academy of Sciences 100(7): 4040-4045.

Sipaúba-Tavares LH, Barros AF \& Braga FMS (2003) Effect of macrophyte cover in the water quality in fishpond. Acta Scientiarum Biological Science 25(1): 27-36.

Sipaúba-Tavares LH, Scardoelli-Truzzi B, Milstein A \& Marcari Marques A (2017) Associated fauna to Eichhornia crassipes in a constructed wetland for aquaculture effluent treatment. Transylvanian Review of Systematical and Ecological Research - The Wetlands Diversity 19(1): 29-42.

Tibúrcio VG, Arrieira RL, Schwind LTF, Bonecker CC \& Laansac-Tôha FA (2015) Effects of nutrients increase on the copepod community of a reservoir using cages. Acta Limnologica Brasiliensia 3(3): 265-274.

Thomaz SM, Bini LM \& Pagioro TA (2004) Methods in Limnology: Water Macrophytes In: Bicudo CEM \& Bicudo DC (eds) Sampling in Limnology, RIMA, Brazil, pp. 193-210. (in Portuguese)

Travaini-Lima F, Milstein A \& Sipaúba-Tavares LH (2016) Seasonal differences in plankton community and removal efficiency of nutrients and organic matter in a subtropical constructed wetland. Wetlands 36(5): 921-933. 
Valentin JL (2000) Numerical Ecology: An Introduction to Multivariate Ecological Data Analysis. Interciência, 117 p. (in Portuguese)

Van Onsem S, Backer S \& Triest L (2010) Microhabitat-zooplankton relationship in extensive macrophyte vegetation of eutrophic clear-water ponds. Hydrobiologia 656: 67-81.

Zrum L \& Hann BJ (1997) Planktonic micro-invertebrate community structure in a prairie wetland in response to addition of inorganic nutrients and organophoshorus insecticide. UFS (Delta Marsh). Annual Report 32: 56-67. 